\title{
KEMAMPUAN MENYUSUN HIPOTESIS DALAM PEMBELAJARAN IPA MELALUI METODE EKSPERIMEN PADA PESERTA DIDIK KELAS V SEKOLAH DASAR
}

\author{
Ai Salsiah \\ Mahasiswa S2 Pendidikan Dasar Universitas Negeri Jakarta \\ Aisalsiah67@gmail.com
}

\begin{abstract}
This Research aimed at increasing the ability compiled hypothesis in Scientific Learning through the experiment method. This Research is done at SD Negeri Pajeleran 01 located at Jl. Dadi Kusmayadi kelurahan Sukahati Kecamatan Cibinong. Research is an action research class room. The observation Result that the average of students score in scientific subject got higher from 68 become $80, \mathrm{KKM}$ achievements increase as high as $23 \%$ and the ability compiles hypothesis at each indicator is increase from 2,99 to 3,22, logical indicator increase 3,19 to 3,21 and deductive indicator increase from 2,90 to 3,20. The Rule of teacher action and participant have reached $100 \%$. This research Result can become input for teacher to apply experiment method in compiling hypothesis at scientific learning.
\end{abstract}

Keyword : Compile hypothesis, natural science, eksperimen, elementary school.

\begin{abstract}
Abstrak: Penelitian ini bertujuan meningkatkan kemampuan meyusun hipotesis melalui metode ilmiah percobaan .Penelitian ini ini dilakukan pada SD Negeri Pajeleran 01 yang terletak di j1 .Dadi kusmayadi kelurahan Sukahati Kecamatan Cibinong Kabupaten bogor. Jenis penelitian ini adalah PTK kemimis serta mc . Pengamatan hasil bahwa rata-rata siswa mencetak gol ilmiah tunduk punya lebih besar dari 68 menjadi 80 , prestasi meningkatkan setinggi $\mathrm{kkm} 23 \%$ dan kemampuan mengkompilasi hipotesis di setiap indikator mengalami peningkatan untuk semua dari 2,99 untuk 3,22, indikator meningkatkan 3,19 untuk 3,21 logis dan indikator deduktif meningkat dari 2,90 untuk 3,20 .Supremasi guru tindakan dan peserta telah mencapai $100 \%$ .Hasil penelitian ini dapat menjadi masukan bagi guru untuk menerapkan percobaan metode ilmiah dalam kompilasi hipotesis di belajar.
\end{abstract}

Kata Kunci : Menyusun hipotesis, pembelajaran ilmu pengetahuan alam, eksperimen, sekolah dasar

Perkembangan dan perubahan yang terjadi dalam kehidupan masyarakat tidak terlepas dari pengaruh perubahan global, perkembangan ilmu pengetahuan dan teknologi, seni, budaya serta informatika saat ini sangat mempengaruhi bidang kehidupan masyarakat yang semakin kompleks, manusia dituntut aktif untuk bisa bertindak cepat, cermat, kritis dan kreatif, berwawasan, serta bermoral dan berbudaya sehingga bisa bersaing dengan negara-negara lain. Untuk menghadapi perkembangan dan perubahan yang terus menerus ini menuntut perlunya perbaikan sistem pendidikan yang dapat menyesuaikan dengan perubahan zaman tersebut.

Hal ini tidak mudah diwujudkan dan bukan suatu pekerjaan yang ringan, terutama masalah internal yang dihadapi pendidikan dewasa ini, dari mulai pendidikan dasar sampai perguruan 
Kemampuan Menyusun Hipotesis

Al Salsiah

tinggi, khususnya di Sekolah Dasar adalah rendahnya kualitas dan penguasaan terhadap IPA.

Rendahnya kualitas pada jenjang Sekolah Dasar sangat penting untuk segera diatasi karena sangat berpengaruh pada jenjang pendidikan selanjutnya.

Permasalahan-permasalahan internal tersebut antara lain rendahnya mutu akademik terutama penguasaan Ilmu Pengetahuan Alam, padahal penguasaan materi tersebut merupakan kunci dalam menguasai dan mengembangkan ilmu pengetahuan dan teknologi (Siskandar, 2010: 87-88). Dalam pembelajaran IPA hal yang harus diperhatikan selain penguasaan teori juga praktek sehingga ada keseimbangan antara teori yang dipelajari dengan pembuktiannya supaya ilmu pengetahuan dapat dipahami peserta didik dengan baik dan dapat bermanfaat bagi hidupnya.

Mengamati pembelajaran yang berlangsung, diketahui bahwa pembelajaran IPA yang selama ini terjadi cenderung ke arah teoritis, bersifat hapalan, dan masih berpusat pada guru, kebiasaan yang terjadi setelah menerima informasi dari guru peserta didik berusaha untuk menghapalkan materi yang diberikan. Guru kurang berusaha mengembangkan dengan cara membuktikan melalui metode yang sesuai sehingga penerapannya nyata dalam kehidupan seharihari peserta didik.

Rendahnya kualitas pembelajaran IPA, menuntut dilakukan perbaikan segera terhadap proses pembelajaran IPA di tingkat Sekolah Dasar dan perubahan dalam masyarakat yang dinamis menuntut adanya penyesuaianpenyesuaian dalam proses pendidikan yang senantiasa berada dalam satu dinamika perubahan dan perkembangan, sehingga memberikan tantangan bagi guru untuk terus menerus mencari solusi supaya dapat meningkatkan pembelajaran IPA dalam keterampilan dasar.

Terdapat beberapa keterampilan dasar yang harus dilakukan dan dilatih supaya mahir dan mampu mempelajari sains dengan baik, yaitu observasi dan inferensi, pengukuran dan estimasi, mengajukan pertanyaan dan merumuskan masalah, komunikasi dan interpretasi, prediksi dan berhipotesis, definisi operasional, identifikasi dan pengendalian variabel, serta eksperimen dan penyelidikan (Nuryani Rustaman, 2010: 1.10). Dengan memperhatikan beberapa keterampilan dasar yang harus dilakukan dan dilatih supaya mahir dan mampu mempelajari sains dengan baik, dalam hal ini diambilah salah satunya yaitu berhipotesis. Dengan melaksanakan salah satu keterampilan dasar ini, peserta diusahakan untuk terlibat aktif dalam pembelajaran sehingga materi pelajaran mudah dikuasai. 
Dalam mengembangkan salah satu keterampilan dasar ini, tidak saja mementingkan hasil tetapi juga memperhatikan proses, karena peserta didik seharusnya belajar dengan proses yang bermakna bahwa IPA diajarkan sebagai suatu cara berpikir untuk membangun struktur kognitif, afektif, dan psikomotornya yang merupakan tanggga untuk meraih tingkat keberhasilan yang diharapkan. Dengan mengetahui proses, peserta didik dapat menemukan hal-hal baru sebagai daya cipta sehingga akhirnya dapat membentuk manusia yang berkualitas.

Sekolah sebagai lembaga pendidikan membantu mengembangkan potensi yang dimiliki peserta didik melalui proses pembelajaran, sarana, media, sumber, dan tenaga kependidikan sebagai fasilitator yang membantu mendorong dan membimbing peserta didik dalam pembelajaran untuk memperoleh keberhasilan dalam belajar. Perubahan hasil dapat dilihat dari berbagai bentuk, seperti berubahnya pengetahuan, tingkah laku, sikap, keterampilan, maupun kemampuan.

Istilah competencies, competence dan competent diterjemahkan sebagai kompetensi, kecakapan, keberdayaan merujuk pada "keadaan atau kualitas mampu dan sesuai" (Martinis Yamin, Maisah, 2010: 1). Kemampuan manusia telah ada sejak lahir dan kemampuan yang lainnya memerlukan belajar dengan baik dan sungguh-sungguh untuk meraihnya.

Kemampuan yang pertama tersedia tanpa dipelajari lebih dahulu sudah ada sejak lahir yang disebut insting antara lain, "kemampuan mengamati, kemampuan menghayati ketegangan emosi, dan kemampuan berbuat" (Uyoh Sadulloh, 2007: 10).

Untuk mencapai tujuan dalam hidupnya, manusia tidak saja menggunakan instingnya tetapi perlu belajar untuk mencapai suatu tujuan yang diinginkan. Kemampuan (Kompetensi) adalah "perilaku rasional” untuk mencapai tujuan yang memuaskan pada kondisi yang diinginkan (Oemar Hamalik, 2010: 311). Untuk menghadapi kehidupannya, manusia membutuhkan kemampuan yang dapat digunakan untuk memecahkan persoalan dalam mencapai tujuan yang diinginkan. Ahli lain berpendapat bahwa kemampuan merupakan "hasil belajar" (Muhammad Ali, 2008: 74).

Seorang ilmuwan yang melakukan penelitian menggunakan aturan dan langkahlangkah umum yang sama. Langkah ini disebut metode ilmiah, peserta didik sebagai calon ilmuwan perlu diperkenalkan dan diberi bekal supaya mampu melaksakannya, salah satu langkah dalam metode ilmiah adalah membuat hipotesis. 
Kemampuan Menyusun Hipotesis

Al Salsiah

Menurut Gunawan Undang (2009: 44), Hipotesis merupakan jawaban atas pertanyaan yang sudah dirumuskan untuk sementara berdasarkan tinjauan pustaka atau hasil deduksi dari suatu teori, pemikiran logis, atau pengalaman. Sejalan dengan hal tersebut, dapat dijelaskan bahwa dalam kegiatan penelitian, berhipotesis perlu didukung data untuk diterima. Hipotesis sering dinamakan jawaban sementara atau dugaan terhadap rumusan masalah yangg berupa pertanyaan. Berhipotesis disebut jawaban sementara atau dugaan karena memang jawaban tersebut masih perlu diuji kebenarannya untuk dapat diterima karena didukung data, atau ditolak karena tidak didukung data.

Metode ilmiah merupakan prosedur kerja sistematis yang terencana, pengkajiannya bersumber pada data empiris yang diperoleh dengan cermat menggunakan berbagai cara sesuai dengann aturan untuk dapat memecahkan suatu masalah. Pembelajaran IPA ditujukan terutama untuk menguasai konsep-konsep IPA yang aplikatif dan bermakna bagi kehidupan. Dalam bekerja ilmiah maupun dalam metode ilmiah didalamnya terdapat keterampilan proses sains. Mempunyai kemampuan tentang sains tidak hanya sekedar mengetahui materi tentang sains, tetapi terkait pula dengan memahami bagaimana cara untuk mengumpulkan fakta dan menghubungkan fakta-fakta sehingga dapat memiliki kemampuan menyusun hipotesis.

Dalam pandangan konstruktivisme bahwa pengetahuan seseorang terkait dengan pengalaman dan pentingnya mengingat dan mengungkapkan melalui pengalaman seseorang dapat mengkonstruksi pengetahuan. Dalam proses konstruksi, peserta didik yang aktif sangat diperlukan agar pembelajaran dapat berhasil. Keterlibatan peserta didik yang aktif aktif terjadi pada waktu kegiatan kognitif dalam perolehan pengetahuan.

Ilmu merupakan pengetahuan yang mampu mendeskripsikan, menjelaskan memprediksi gejala alam termasuk manusia dan permasalahannya dalam kehidupan sehari-hari dan dapat menggunakan pengetahuan ilmiah dalam pemecahannya. Pengetahhuan ilmiah baru berfungsi apabila dilakukan penalaran. Tanpa penalaran pengetahuan ilmiah tidak akan berfungsi secara optimal dalam pemecahannya masalah. Jujun S. Suriasumantri (2010: 114) mengemukakan bahwa penalaran adalah aktivitas berpikir yang dalam kegiatannya mempergunakan alat berpikir, selanjutnya secara filosofis dapat dikatakan bahwa pengetahuan ilmiah adalah logis bila ditinjau secara rasional dan teruji bila ditinjau secara empiris.

Upaya peserta didik untuk memecahkan masalah yang dihadapinya dilakukan melalui kegiatan penelitian yang mencerminkan 
metode ilmiah serta mementingkan proses yang memungkinkan peserta didik dapat menggunakan alur pikir yang sistematis dalam memperoleh hasil. Sifat deduktif hipotesis dapat digunakan untuk memecahkan suatu masalah.

Menurut Uus Toharudin, Sri Hendrawati, Andrian Rustaman (2011: 163) Sifat deduktif hipotesis meliputi penyelesaian masalah. Dalam menyelesaikan suatu masalah seseorang akan mengawalinya dengan pemikiran teoritik, kemudian menganalisis sebuah masalah dan mengajukan cara-cara penyelesaian hipotesis yang mungkin atas masalah itu. Berdasarkan paparan di atas disimpulkan bahwa kemampuan menyusun hipotesis adalah proses internal otak seseorang dalam kemampuan memberikan jawaban sementara atau dugaan dengan indikator pengalaman, logis dan deduktif.

Bekerja secara ilmiah dalam sains merupakan cara-cara memahami gejala alam yang terus berkembang. Hal ini sangatlah menantang dan menarik bagi peserta didik. Untuk dapat memupuknya diperlukan guru yang mampu menciptakan suasana pembelajaran yang kondusif. Guru harus mampu memberikan dorongan, tantangan dan menarik minat peserta didik dalam melakukan pembelajaran secara optimal. Dengan pembelajaran optimal tersebut diharapkan tujuan pembelajaran IPA dapat tercapai.
Kenyataan dilapangan dalam pembelajaran IPA sangat membosankan, guru tidak mampu menciptakan suasana belajar yang kondusif sehingga peserta didik kurang tertarik untuk belajar IPA. Metode yang digunakan guru masih bersifat seadanya, seperti dalam pembelajaran IPA yang selama ini terjadi seringkali bersifat hapalan. Dalam proses pembelajaran peserta didik kurang antusias, karena metode yang digunakan lebih kearah ceramah. Peserta didik kurang diberi kesempatan untuk melakukan percobaan sesuai dengan materi karena kegiatan masih berpusat pada guru. Kondisi tersebut berimplikasi pada rendahnya tingkat penguasaan terhadap materi IPA, sehingga peserta didik kurang memahami materi IPA yang dipelajarinya.

Salah satu kegiatan pembelajaran yang dapat mendorong, menantang, dan menarik minat peserta didik adalah penggunaan metode dalam pembelajaran yang tepat dan benar. Alternatif tindakan pemecahan masalah yang dianggap dapat memberikan solusi bagi terealisasinya proses pembelajaran yang kondusif adalah dengan menggunakan metode eksperimen supaya dapat menarik minat peserta didik, tidak membosankan, memberi kesempatan untuk belajar sambil bekerrja dalam melakukan percobaan.

Menurut Ihat Hatimah, Rudi Susilana, Nuraedi (2007: 14-15), menyatakan bahwa 
Kemampuan Menyusun Hipotesis

Al Salsiah

metode terkait dengan masalah cara kerja agar dapat memahami obyek yang menjadi sasaran ilmu yang bersangkutan. Ada dua kriteria untuk mengukur kadar keilmiahan suatu penelitian yaitu: (1) kemampuan untuk memberi pemahaman tentang pokok permasalahan yang diteliti, (2) Kemampuannya untuk meramalkan yaitu sampai pada suatu kesimpulan yang dapat dicapai jika data yang sama dikemukakan dilain tempat. Metode pembelajaran harus dipilih dan dikembangkan untuk meningkatkan aktivitas dan kreativitas peserta didik salah satu diantaranya adalah metode eksperimen.

\section{Menurut Muhammad Ali (2008: 8),} Eksperimen adalah percobaan tentang sesuatu. Dalam hal ini siswa melakukan percobaan dan bekerja sendiri-sendiri. Pelaksanaan eksperimen lebih memperjelas hasil belajar, karena setiap siswa mengalami dan melakukan kegiatan percobaan.

\section{Menurut Roestiyah (2008: 80),} Eksperimen adalah salah satu cara mengajar, dimana siswa melakukan suatu percobaan tentang suatu hal, mengamati prosesnya serta menuliskan hasil percobaannya, kemudian hasil pengamatan itu disampaikan ke kelas dan dievaluasi oleh guru.

Berdasarkan paparan ahli di atas dapat disimpulkan bahwa metode Eksperimen adalah sebuah langkah-langkah dalam pembelajaran yang menggabungkan teoritis dan pengujian empiris, sehingga peserta didik dapat terlatih dalam cara berpikir ilmiah, rasional dan dengan cara mengujinya dapat menemukan bukti kebenaran dari teori yang sedang dipelajarinya.

Penelitian ini bertujuan untuk meningkatkan kemampuan menyusun hipotesis dalam pembelajaran IPA melalui metode eksperimen pada peserta didik kelas $\mathrm{V}$ SD Negeri Pajeleran 01 Kecamatan Cibinong Kabupaten Bogor.

\section{METODE}

Penelitian ini menggunakan metode kombinasi yaitu penggabungan antara metode kuantitatif dan kualitatif dengan concurrent triangulation (campuran kantitatif dan kualitatif secara berimbang), jenis penelitian gabungan dapat digunakan dalam penelitian tindakan kelas, tujuan utama penelitian tindakan kelas adalah untuk meningkatkan kualitas pembelajaran.

Penelitian ini adalah penelitian tindakan kelas, dilaksanakan dalam dua siklus dengan menggunakan model Kemmis dan MC. Taggart dengan 4 tahapan yang dilaksanakan yaitu: (1) perencanaan (planning), setelah menentukan masalah yang dihadapi dengan observasi awal dan wawancara, kesimpulan yang didapat adalah kurang diberikan perhatian terhadap keterampilan proses sains dalam pembelajaran IPA, peneliti mengambil salah satunya yaitu menyusun hipotesis dan 
kurang diberikan kesempatan peserta didik untuk melakukan percobaan, dalam hal ini metode yang digunakan adalah metode eksperimen. Merencanakan analisis Kurikulum Tingkat Satuan Pendidikan dengan menetukan Standar Kompetensi dan Kompetensi Dasar, menyusun Rencana Pelaksanaan Pembelajaran, membuat instrumen pemantau tindakan, instrumen kemampuan menyusun hipotesis, instrumen tes, mempersiapkan siapa saja yang akan terlibat dalam kegiatan, demikian untuk siklus selanjutnya.(2) pelaksanaan tindakan (acting), merupakan penerapan isi rencana yaitu perlakuan yang dilaksanakan sesuai siklus, jadwal pelajaran yang telah ditetapkan di SDN Pajeleran 01 meliputi 5 jam pelajaran, dilaksanakan dua kali pertemuan dalam satu minggu, 2 jam pelajaran dan 3 jam pelajaran (3) observasi (observing), pada tahapan ini meliputi pengamatan selama tindakan peserta didik dan guru serta pengamatan pada saat proses eksperimen sedang berlangsung, dan (4) refleksi (reflecting), diadakan setelah kegiatan yang dilakukan berlangsung, untuk mengkaji dan menganalisis berbagai kelemahan yang dijadikann acuan untuk menentukan menentukan langkah dalam melaksanakan tindakan pada siklus berikutnya.

Keberhasilan dari tindakan yang dilaksanakan, kriterianya dapat dilihat dari segi guru dan peserta didik. Dari segi peserta didik, tindakan dikatakan berhasil apabila pada siklus tersebut KKM dapat

mencapai nilai $70 \%$, dari segi guru dengan adanya prinsip pembelajaran tuntas, tindakan dikatakan berhasil apabila pada siklus tersebut mencapai kriteria $100 \%$, artinya pembelajaran telah dilaksanakan sesuai dengan tahapantahapan yang telah direncanakan. Apabila kriteria yang telah ditetapkan belum tercapai, peneliti harus melakukan diskusi dan evaluasi, kemudian masuk pada siklus berikutnya, demikian untuk seterusnya sampai tercapai kriteria yang telah ditentukan, maka tindakan penelitian dihentikan. Sumber data adalah: (1) peserta didik kelas VE SDN Pajeleran 01 berjumlah 40 orang tahun pelajaran 2012/2013 dan guru, (2) hasil evaluasi, untuk melihat tingkat kemampuan menyusun hipotesis peserta didik, (3) sumber data pemantau tindakan. Pengumpulan data pada penelitian ini menggunakan teknik tes dan non tes. Teknik tes dilaksanakan dengan memberikan soal-soal sesuai dengan indikator yang telah ditetapkan, teknik non tes meliputi pengamatan, wawancara, dokumentasi dan catatan lapangan. Instrumen kemampuan hipotesis yang dipilih adalah sifat-sifat cahaya. Sebelum menyusun tes terlebih dahulu menyusun kisi-kisi instrumen berdasarkan indikator kemampuan menyusun hipotesis yaitu: (1) pengalaman (2) logis (3) deduktif. Pengujiann validitas dilakukan untuk 
Kemampuan Menyusun Hipotesis

Al Salsiah

mengetahui kevalidan sebuah instrumen, dikatakan valiid apabila instrumen tersebut dapat mengukur apa yang hendak diukur. Pengujian validitas pada penelitian ini dilakukan secara konstruk dan empiris. Validitas isi dilakukan melalui justifikasi pakar (expert judgment) oleh 3 orang ahli.

Pengujian validitas secara empiris ditentukan berdasarkan kriteria internal atau validitas internal, karena instrumen tes uraian, maka skor yang diperoleh adalah skor kontinum (polytomi) dengan rentang nilai 0-4, sehingga digunakan koefisien korelasi product momen. Hasil perhitungan validitas empirik instrumen tes menunjukkan dari 20 butir soal yang dibuat terdapat 4 butir soal tidak valid sehingga tidak bisa digunakan, namun berdasarkan saran ahli, peneliti mengkonstruk keempat soal tersebut dari sisi kalimat yang digunakan sehingga dapat diphami oleh peserta didik, sehingga jumlah instrumen yang digunakan tetap 20.

Reliabilitas adalah sejauhmana hasil pengukuran dapat dipercaya atau ajeg. Pada penelitian ini jenis skor butir kontinum (politomi) oleh karena itu perhitungan koefisien reliabilitas dengan menggunakan koefisien alpha. Hasil perhitungan reliabilitas instrumen tes menunjukkan hasil 0,82 dan hal ini berarti tingkat reliabilitas berada pada tafsiran sangat tinggi, maka dapat disimpulkan bahwa item instrumen dinyatakan reliabel.
Dalam pengumpulan data digunakan 3 teknik yaitu: (1) observasi, dilakukan untuk memperoleh data yang dapat dilihat (2) wawancara, dilakukan untuk menggali data tentang apa yang diucapkan, dipikirkan, dan dirasakan nara sumber. (3) Triangulasi teori yaitu teori tentang kemampuan menyusun hipotesis, teori tentang metode eksperimen dan karakteristik peserta didik. Triangulasi metode yaitu observasi, waancara dan dokumentasi. Analisis data yang dilakukan merupakan suatu proses menyeleksi, mengabstraksikan, mengorganisasikan data secara sistematik, rasional untuk menampilkan bahan-bahan yang dapat digunakan dalam PTK

\section{HASIL}

Pencapaian Keberhasilan Tindakan (Aktivitas guru ) siklus I dan siklus II pada pertemuan 1 sampai dengan pertemuan 4 adalah sebagai berikut: (1) pertemuan 1 siklus I mencapai $70 \%$, pertemuan 1 siklus II mencapai $85 \%$; (2) pertemuan 2 siklus I mencapai $75 \%$, pertemuan 2 siklus II mencapai $100 \%$; pertemuan 3 siklus I mencapai $80 \%$, pertemuan 3 siklus II mencapai $100 \%$;dan pertemuan 4 siklus I mencapai $85 \%$, pertemuan 4 siklus II mencapai $100 \%$.

Pencapaian Keberhasilan Tindakan (Aktivitas peserta didik ) siklus I dan siklus II pada pertemuan 1 sampai dengan pertemuan 4 
adalah sebagai berikut: (1) pertemuan 1 siklus I mencapai $60 \%$, pertemuan 1 siklus II mencapai $80 \%$; (2) pertemuan 2 siklus I mencapai 65\%, pertemuan 2 siklus II mencapai 85\%; pertemuan 3 siklus I mencapai 75\%,pertemuan 3 siklus II mencapai 100\%; dan pertemuan 4 siklus I mencapai $80 \%$, pertemuan 4 siklus II mencapai 100\%.

Rata-rata nilai IPA peserta didik siklus I dan siklus II meningkat dari 68 pada siklus I menjadi 80 pada siklus II. Jumlah pertemuan pada masing -masing siklus adalah 4 kali pertemuan. Untuk nilai terendah juga mengalami kenaikan dari siklus I sebesar 53 naik pada siklus II menjadi 60. Sedangkan untuk nilai tertinggi pada siklus I sebesar 75 mengalami kenaikan pada siklus II menjadi 98. Kenaikan ini terjadi karena peserta didik telah memahami cara menyusun hipotesis dengan benar setelah mendapatkan latihan pada setiap pertemuan.

Pencapaian Nilai KKM IPA peserta didik dari siklus I ke siklus II meningkat. Pada siklus I peserta didik yang mencapai KKM berjumlah 25 orang atau sebesar 62,5\%. Pada siklus II peserta didik yang mencapai KKM berjumlah 34 orang atau sebesar $85 \%$. Terjadi peningkatan pencapaian nilai KKM sebesar 23 $\%$ dari siklus I ke siklus II.

\section{PEMBAHASAN}

Peningkatan kemampuan menyusun hipotesis dari pra siklus, siklus I kemudian ke siklus II pada masing-masing indikator adalah pencapaian rata-rata indikator pengalaman pada pra siklus 2,9 dan siklus I adalah 2,99 kemudian pada siklus II 3,22, untuk nilai ratarata indikator logis pada pra siklus 2,7 dan siklus I adalah 3,19 kemudian meningkat pada siklus II menjadi 3,21 ,sedangkan rata-rata nilai indikator deduktif pada pra siklus 2,5 dan siklus I adalah 2,90 meningkat pada siklus II menjadi 3,20. Masing-masing indikator mengalami peningkatan seperti pada indikator pengalaman, dalam proses menyusun hipotesis keterlibatan peserta didik yang aktif sangat diperlukan pada waktu kegiatan psikis dengan menggunakan pengetahuan sebelumnya dalam memecahkan masalah yang dihadapi. Pada indikator logis peserta didik sudah memiliki kemampuan menyampaikan pikiran secara logis karena peserta didik kelas V berada pada fase perkembangan tahap operasional konkret (7-11 tahun) dan tahap operasional formal (1115 tahun) menurut Piaget dalam Santrock pada tahap operasional konkret, pemikiran logis menggantikan pemikiran intuitif dalam situasi konkret, pada tahap operasional formal, dari konkret ke yang lebih abstrak dan logis sangat cocok untuk kemampuan menyusun hipotesis dengan indikator logis, menggunakan metode eksperimen dalam proses situasi konkret, dibuktikan tidak hanya sekedar teori. Pada Indikator deduktif memerlukan latihan karena peserta didik pada umumnya belum mampu 
Kemampuan Menyusun Hipotesis

Al Salsiah

menggunakan teori yang bersifat umum ke khusus . Rentang nilai adalah 0-4,0 (data terlampir). Berikut adalah grafik nilai rata-rata kemampuan menyusun hipotesis peserta didik pada pra siklus, siklus I dan siklus II.

\section{SIMPULAN}

Berdasarkan hasil analisis data, interpretasi hasil analisis dan pembahasan, maka dapat diambil beberapa kesimpulan sebagai berikut :

1. Perencanaan pembelajaran untuk meningkatkan kemampuan menyusun hipotesis dalam pembelajaran IPA melalui metode eksperimen pada peserta didik kelas V SD Negeri Pajeleran 01 Kecamatan Cibinong Kabupaten Bogor, dimulai dengan menyiapkan Rencana. Guru juga menyiapkan media untuk eksperimen dan bahan ajar serta LKS .Sesuai dengan hasil observasi tindakan yang dilakukan observer terhadap tindakan atau aktivitas guru dan peserta didik selama pembelajaran IPA berlangsung, hasil catatan lapangan tentang temuan dalam penelitian, hasil dokumentasi dan wawancara yang dilakukan peneliti kepada peserta didik, maka langkah-langkah pembelajaran dengan menggunakan metode eksperimen yang diterapkan, terus mengalami kemajuan berarti pada setiap siklus sesuai dengan target yang telah ditentukan dalam perencanaan, sehingga pada akhir siklus II proses pembelajaran telah berhasil dan tuntas yaitu telah mencapai indikator keberhasilan tindakan $100 \%$.

2. Proses pelaksanaan pembelajaran untuk meningkatkan kemampuan menyusun hipotesis dalam pembelajaran IPA melalui metode eksperimen pada peserta didik kelas V SD Negeri Pajeleran 01 Kecamatan Cibinong Kabupaten Bogor difokuskan pada pengembangan peserta didik dalam mengaplikasikan pengalaman yang dimilikinya untuk menjadi bahan menyusun hipotesis, kegiatan berpikir yang bersifat logis serta menuangkan konsep bersifat deduktif dari umum ke khusus dalam menyelesaikan masalah tanpa kehilangan ciri utama metode pembelajaran eksperimen, yaitu peserta didik melakukan percobaan-percobaan secara individu juga secara kelompok yang sangat menunjang keberhasilan pencapaian tujuan pembelajaran secara optimal dengan metode eksperimen ini, karena peserta didik dapat secara langsung menyusun hipotesis kemudian menemukan solusi dari masalah yang disajikan.

3. Evaluasi pembelajaran untuk meningkatkan kemampuan menyusun hipotesis dalam pembelajaran IPA melalui metode eksperimen pada peserta didik kelas V SD Negeri Pajeleran 01 Kecamatan Cibinong Kabupaten Bogor 
dilakukan dengan tes tertulis setelah melaksanakan eksperimen. Evaluasi dilakukan untuk mengukur peningkatan kemampuan menyusun hipotesis peserta didik. Peningkatan kemampuan menyusun hipotesis ditandai dengan peningkatan dilihat dari hasil observasi siklus I ke siklus II yang terus mengalami peningkatan. Pada akhir siklus II rata-rata nilai IPA peserta didik dari 68 naik menjadi 80, nilai terendah peserta didik naik dari 53 menjadi 60, nilai tertinggi peserta didik naik dari 75 menjadi 98, pencapaian KKM peserta didik naik dari $68 \%$ menjadi $85 \%$ serta kemampuan menyusun hipotesis dengan indikator pengalaman pada siklus I rata-rata 2,99 naik pada siklus II mencapai 3,22, indikator logis pada siklus I rata-rata 3,19 naik pada siklus II mencapai 3,21, indikator deduktif pada siklus I rata-rata 2,90 naik pada siklus II mencapai 3,20 (rentang nilai 0-4).

4. Peningkatan kemampuan menyusun hipoesis peserta didik perlu penekanan pada semua indikator yaitu pengalaman, logis, dan deduktif. Peserta didik belum terlatih bagaimana menggunakan pengalaman yang dimiliki menjadi sebuah bahan menyusun hipotes. Untuk indikator logis, hal ini ditunjang oleh usia perkembangan pesrta didik kelas $\mathrm{V}$ yang berada pada kisaran usia 11 sampai 12 tahun yang berada pada fase perkembangan tahap operasional konkret (7-11 tahun) dan tahap operasional formal (11-15 tahun) menurut Piaget dalam Santrock pada tahap operasional konkret, pemikiran logis menggantikan pemikiran intuitif dalam situasi konkret, pada tahap operasional formal, dari konkret ke yang lebih abstrak dan logis sangat cocok untuk kemampuan menyusun hipotesis dengan indikator logis, menggunakan metode eksperimen dalam proses situasi konkret, dibuktikan tidak hanya sekedar teori.

\section{DAFTAR RUJUKAN}

Ali, Muhammad. 2008. Guru dalam Proses Belajar Mengajar. Bandung: Sinar Baru Algesindo.

Hatimah, Ihat, dan Susilana. 2007. Penelitian Pendidikan. Bandung: UPI PRESS.

Roestiyah. 2008. Strategi Belajar Mengajar. Jakarta: Rineka Cipta.

Sadulloh, Uyoh. 2007. Pedagogik. Bandung: Cipta Utama.

Suriasumantri, Jujun S. 2011. Menguak Cakrawala Keilmuan. Jakarta: Program Pasca Sarjana Universitas Negeri Jakarta.

Toharudin, Uus. 2011. Membangun Literasi Sains Peserta Didik. Bandung: Humaniora. 
Kemampuan Menyusun Hipotesis

Al Salsiah

Undang Gunawan. 2009. Teknik Penelitian Tindakan Kelas. Bandung:

Sayagatama.

Yamin, Martinis. 2011. Standarisasi Kinerja Guru. Jakarta: Gaung Persada. 